\title{
Border disease in persistently infected calves: radiological and pathological findings
}

Frei, S ; Braun, Ueli ; Dennler, Matthias ; Hilbe, Monika ; Stalder, H P ; Schweizer, M ; Nuss, Karl

DOI: https://doi.org/10.1136/vr.102095

Posted at the Zurich Open Repository and Archive, University of Zurich

ZORA URL: https://doi.org/10.5167/uzh-99456

Journal Article

Accepted Version

Originally published at:

Frei, S; Braun, Ueli; Dennler, Matthias; Hilbe, Monika; Stalder, H P; Schweizer, M; Nuss, Karl (2014). Border disease in persistently infected calves: radiological and pathological findings. Veterinary Record, 174(7):170.

DOI: https://doi.org/10.1136/vr.102095 
Border Disease in persistently infected calves: Radiologic and pathologic findings.

Sandra Frei ${ }^{\text {a) }}$, Ueli Braun ${ }^{\text {a) }}$, Matthias Dennler ${ }^{\text {b) }}$, Monika Hilbe ${ }^{\text {c) }}$, Hanspeter Stalder ${ }^{\text {d), }}$ Matthias Schweizer ${ }^{\text {d) }}$, Karl Nuss ${ }^{\text {a), * }}$

a) Department of Farm Animals, Vetsuisse Faculty, University of Zurich, Winterthurerstrasse 260, 8057 Zurich, Switzerland

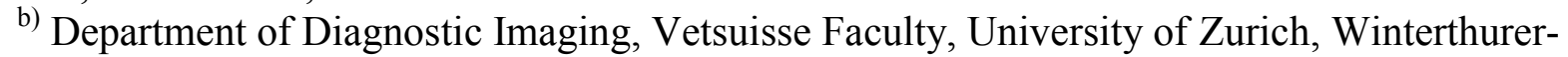
strasse 260, 8057 Zurich, Switzerland

${ }^{c}$ Institute of Veterinary Pathology, Vetsuisse Faculty, University of Zurich, Winterthurerstrasse 268, 8057 Zurich, Switzerland

d) Institute of Veterinary Virology, Vetsuisse Faculty, University of Bern, Laenggassstrasse 122, 3001 Bern, Switzerland

* Karl Nuss

Tel.: +41-44-6359031

knuss@vetclinics.uzh.ch 
Border disease (BD) virus belongs to the genus Pestivirus together with bovine viral diarrhoea virus genotypes 1 and 2 (BVDV-1 and -2) and classical swine fever virus (CSFV) (Pletnev and others 2011). The pathogenicity of BD virus for bovine fetuses has been recognised early (Gibbons and others 1974), but only since 1994 renewed attention has been drawn to the mutual transmission between species (Carlsson and Belák 1994). Transmission of BD virus from persistently infected sheep to cattle was demonstrated (Krametter-Frötscher and others 2008; Krametter-Frötscher and others 2009; Reichle 2009; Braun and others 2013a; Braun and others 2013b). Nevertheless, reports on clinical disease in cattle caused by BD virus are rare (Cranwell and others 2007; Krametter-Frötscher and others 2010; McFadden and others 2012).

The present report describes the radiologic and pathologic findings in three calves (Table 1) persistently infected with BD virus. Persistent infection with pestivirus was suspected based on an initial positive ear notch sample taken within one week after birth on the three different farms of origin and tested in private laboratories by ELISA or RT-PCR. This was later confirmed in our lab using real-time RT-PCR and serology on blood samples collected independently on at least two occasions, a minimum of 17 days apart. Thus, all calves were strongly positive for viral RNA and negative for serum antibodies against pestiviruses at the latest time point analysed, i.e. at the age of 2, 8, and 15 month after birth for animal 1,2, and 3 , respectively. This identifies all three calves as persistently infected with a pestivirus. Genotyping based on the sequence within the 5' untranslated region (5'-UTR) of the pestiviral genome (Bachofen and others 2008) revealed that calves were persistently infected with BD virus 'Switzerland' (Peterhans and others 2010). This was corroborated by the facts that (i) the mother animals of all three calves possessed significantly higher neutralising antibodies against $\mathrm{BD}$ virus than BVDV as assessed by serum neutralisation tests (SNT), and that (ii) sheep were kept on all three farms from where the PI animals originated. For further diagnostic investigation, immunohistochemistry using monoclonal antibodies against virus antigens 
was carried out on snap-frozen skin biopsy specimens (calf 1 to 3; Ca3/34-C42, specific for BVDV and antibody C16, specific for pestivirus) as described (Hilbe and others 2007). The staining with pestivirus-specific antibodies was positive and with BVDV-specific ones negative in all of the three calves, in accordance with BD virus infections.

Calf 1 had a moderate body condition and appeared stocky, calves 2 and 3 were in good body condition with a normal demeanor at the time of admission. Radiographic evaluation of calf 2 was undertaken 52 days after admission because of right hind limb lameness and swelling of the lateral aspect of the right stifle. Radiographs showed bands of increased radiopacity in the proximal tibial and distal femoral metaphyses.

Consequently radiographs of the left metacarpus and metatarsus were taken in all three calves. Radiographic examination was repeated 5 months after the initial examination in calf 2. Computed tomographic (CT) examination of the left fore- and hindlimbs was carried out in calf 1 and calf 2 (Table 1). CT in calf 2 was carried out under general anaesthesia, in calf 1 at postmortem since it had to be euthanised because of enteritis, bronchopneumonia and omphalitis. The calves were scanned in lateral recumbency using $120 \mathrm{kVp}, 200 \mathrm{~mA}$ and the pictures evaluated in a bone and soft tissue window.

Radiographs in calf 1 (Fig. 1) showed concentric radiopaque rings in the carpal and tarsal bones as well as in the epiphyses of the radius, tibia, metacarpal and metatarsal bones and phalanges. The metaphyses of the long bones had multiple, alternating, parallel bands of high and low radiopacity. The medullary radiopacity of the bones was increased but was homogeneous without apparent structure, the cortex was thickened and the diameter of the bones appeared reduced (Fig. 1 a). Computed tomography revealed generalized severe trabecular sclerosis of all examined bones. The carpal, tarsal and phalangeal bones had concentric zones of greatly increased attenuation (Fig. 1 b). The radiologic diagnosis was chronic, severe, generalised recurrent osteopetrosis with secondary moderate abnormalities of the shape and structure of the long bones. 
Radiographs in calf 2 showed parallel transverse bands of increased radiopacity in the metaphyses of the metacarpi, -tarsi and digits (Fig. 2 a, c) and irregular, increased radiopacity of the medullary cavity of the metacarpal / metatarsal bones. The trabecular sclerosis in all bones as well as alterations in the shape and structure of the cortex of long bones were less pronounced overall in the images of the computed tomography than those seen on radiographs. In calf 2, radiographs taken at the age of eight months exhibited milder changes than at the age of three months (Fig. 2 b, d). The banding in the metaphyses was replaced with inhomogeneous moderate sclerosis, indicating regressive osteopetrosis.

The radiographic findings in calf 3 consisted of a mild increase in radiopacity of the diaphyses which extended to the metaphyses. The metaphyseal vascular channels were accentuated by neighbouring sclerosis, indicating mild osteopetrosis.

In necropsy the left fore- and hind limb of calf 1 were cut in the transverse plane revealing mostly striate, but sometimes circular white dense bone structures alternating with normal bone ('bone-in-bone') in the epiphyses and metaphyses of the humerus, radius, ulna, os femoris, tibia, metacarpal and metatarsal bones and phalanges (Fig. 2 c). After gross examination, the bones were sawed into small pieces, fixed in formalin for 24 hours and then decalcified with EDTA-citrate acid for 4 weeks. Histological examination of the white areas yielded a marked increase in small, plump, retained primary trabeculae (osteopetrosis) that were interwoven transversely and longitudinally and formed the so-called 'growth arrest lines'. Between these structures were slender, partly interwoven, normal primary trabeculae, which were slightly decreased in number (mild osteoporosis). There were a scant number of osteoblasts and even fewer osteoclasts visible. Immunohistochemistry using monoclonal antibodies against the virus antigen $\mathrm{E}^{\mathrm{rns}}$ (C42, specific for BVDV and 15C5, specific for pestiviruses) was carried out on paraffin-embedded material of various organs (Hilbe and others 2007) and on decalcified bone material (Hilbe and others 2000; Nuss and others 2005). All samples were positive with pestiviruses-specific but negative with BVDV-specific antibodies. In bone mate- 
rial, pestivirus antigen was visible multifocally in osteocytes.

The present cases document, to our knowledge for the first time, radiologic and pathologic changes in bone structure in three calves born persistently infected with BD virus after natural, transient infections of their mother animals, analogous to changes described in aborted bovine fetuses persistently infected with BD virus (Gibbons et al., 1974) and bovine fetuses and calves persistently infected with BVDV (Constable and others 1993; O'Connor and Doige 1993; Scruggs and others 1995; Hilbe and others 2000; Nuss and others 2005; Smirnova and others 2008; Webb and others 2012). The severity of clinical and radiologic changes varied with the individual calves; the calf with the most severe clinical signs also had the most severe radiologic and histologic lesions. Similar to radiographic lesions in a calf persistently infected with BVDV (Nuss and others 2005), clinical and radiographic signs improved with age in calf 2, and were hardly visible in calf 3 , which was radiographed at the age of 16 months. This indicates that persistent infection with BD and BVD virus in calves can basically be diagnosed radiographically provided that radiographs are taken in the first few weeks of life, when changes are still distinct. Radiographic and pathologic changes in calves persistently infected with BD virus are not readily distinguishable from lesions in calves persistently infected with BVDV. Therefore, both viruses should be considered equally pathogenic for cattle.

Conflict of interest statement: None of the authors of this paper has a financial or personal relationship with other people or organisations that could inappropriately influence or bias the content of the paper. 
124 Acknowledgements: We thank Dr. Joseph Risi and Dr. Toni Linggi from the Veterinary Of-

125 fice of the founding cantons for identifying and referring the calves and Ivo Campagna from 126 the Department of Anaesthesiology, University of Zurich, for anaesthesia of the calf. 
References

BACHOFEN, C., STALDER, H. P., BRAUN, U., HILBE, M., EHRENSPERGER, F. \& PETERHANS, E. (2008) Co-existence of genetically and antigenically diverse bovine viral diarrhoea viruses in an endemic situation. Veterinary Microbiology 131, 93-102 BRAUN, U., BACHOFEN, C., BÜCHI, R., HÄSSIG, M. \& PETERHANS, E. (2013a) Infection of cattle with Border disease virus by sheep on communal alpine pastures. Schweizer Archiv für Tierheilkunde 155, 123-128

BRAUN, U., REICHLE, S. F., REICHERT, C., HÄSSIG, M., STALDER, H. P., BACHOFEN, C. \& PETERHANS, E. (2013b) Sheep persistently infected with Border disease readily transmit virus to calves seronegative to BVD virus. Veterinary Microbiology in press CARLSSON, U. \& BELÁK, K. (1994) Border disease virus transmitted to sheep and cattle by a persistently infected ewe: epidemiology and control. Acta Veterinaria Scandinavica 35, $79-88$

CONSTABLE, P. D., HULL, B. L., WICKS, J. R. \& MYER, W. (1993) Femoral and tibial fractures in a newborn calf after transplacental infection with bovine viral diarrhoea virus. Veterinary Record 132, 383-385 CRANWELL, M. P., OTTER, A., ERRINGTON, J., HOGG, R. A., WAKELEY, P. \& SANDVIK, T. (2007) Detection of Border disease virus in cattle. Veterinary Record 161, 211-212

GIBBONS, D. F., WINKLER, C. E., SHAW, I. G., TERLECKI, S., RICHARDSON, C. \& DONE, J. T. (1974) Pathogenicity of the border disease agent for the bovine foetus. British Veterinary Journal 130, 357-360

HILBE, M., OSSENT, P., ZLINSZKY, K. \& EHRENSPERGER, F. (2000) Abnormal bone development associated with bovine virus diarrhea virus (BVDV) infection in a newborn calf. European Journal of Veterinary Pathology 6, 115-119

HILBE, M., STALDER, H., PETERHANS, E., HAESSIG, M., NUSSBAUMER, M., EGLI, C., SCHELP, C., ZLINSZKY, K. \& EHRENSPERGER, F. (2007) Comparison of five diagnostic methods for detecting bovine viral diarrhea virus infection in calves. Journal of Veterinary Diagnostic Investigation 19, 28-34

KRAMETTER-FRÖTSCHER, R., BENETKA, V., MÖSTL, K. \& BAUMGARTNER, W. (2008) Transmission of Border Disease Virus from sheep to calves - a possible risk factor for the Austrian BVD eradication programme in cattle? Wiener Tierarztliche Monatsschrift 95, 200-203

KRAMETTER-FRÖTSCHER, R., BENETKA, V., RASSER, K., TOCKNER, F., MÖSSLACHER, G., MÖSTL, K. \& BAUMGARTNER, W. (2009) BVDV control program in Austria - is a monitoring of the BDV status in sheep in Austria necessary? Veterinarni Medicina 54, 517-524

KRAMETTER-FRÖTSCHER, R., MASON, N., RÖTZEL, J., BENETKA, V., BAGO, Z., MÖSTL, K. \& BAUMGARTNER, W. (2010) Effects of Border disease virus (genotype 3) naturally transmitted by persistently infected sheep to pregnant heifers and their progeny. Veterinarni Medicina 55, 145-153 MCFADDEN, A. M., TISDALL, D. J., HILL, F. I., OTTERSON, P., PULFORD, D., PEAKE, J., FINNEGAN, C. J., LA ROCCA, S. A., KOK-MUN, T. \& WEIR, A. M. (2012) The first case of a bull persistently infected with Border disease virus in New Zealand. New Zealand Veterinary Journal 60, 290-296 NUSS, K., SPIESS, A., HILBE, M., STERR, K., REISER, M. \& MATIS, U. (2005) Transient benign osteopetrosis in a calf persistently infected with bovine virus diarrhoea virus. Veterinary and Comparative Orthopaedics and Traumatology 18, 100-104

O'CONNOR, B. P. \& DOIGE, C. E. (1993) Abnormal modeling of trabecular bone in calves. Canadian Journal of Veterinary Research 57, 25-32

PETERHANS, E., BACHOFEN, C., STALDER, H. \& SCHWEIZER, M. (2010) Cytopathic 
179 bovine viral diarrhea viruses (BVDV): emerging pestiviruses doomed to extinction. Veteri-

180 nary Research 41, 44

181 PLETNEV, A., GOULD, E., HEINZ, F. X., MEYERS, G., THIEL, H.-J., BUKH, J., STIASNY, K., COLLETT, M. S., BECHER, P., SIMMONDS, P., RICE, C. M. \& MONATH, T. P. (2011) Flaviviridae. In Virus Taxonomy. 9th edn. Eds A. M. Q. KING, M. J. ADAMS, E. B. CARSTENS, E. J. LEFKOWITZ. Oxford, Academic Press. pp 1003-1020 REICHLE, S. F. (2009) Untersuchungen bei Kälbern, die mit Border-Disease infizierten Lämmern zusammengehalten werden. In Vetsuisse Faculty Switzerland, University of Zurich SCRUGGS, D. W., FLEMING, S. A., MASLIN, W. R. \& GROCE, A. W. (1995) Osteopetrosis, anemia, thrombocytopenia, and marrow necrosis in beef-calves naturally infected with bovine virus diarrhea virus. Journal of Veterinary Diagnostic Investigation 7, 555-559 SMIRNOVA, N. P., BIELEFELDT-OHMANN, H., VAN CAMPEN, H., AUSTIN, K. J., HAN, H., MONTGOMERY, D. L., SHOEMAKER, M. L., VAN OLPHEN, A. L. \& HANSEN, T. R. (2008) Acute non-cytopathic bovine viral diarrhea virus infection induces pronounced type I interferon response in pregnant cows and fetuses. Virus Research 132, 49-58 WEBB, B. T., NORRDIN, R. W., SMIRNOVA, N. P., VAN CAMPEN, H., WEINER, C. M., ANTONIAZZI, A. Q., BIELEFELDT-OHMANN, H. \& HANSEN, T. R. (2012) Bovine viral diarrhea virus cyclically impairs long bone trabecular modeling in experimental persistently infected fetuses. Veterinary Pathology 49, 930-940 
Table 1 Data of calves persistently infected with BD virus at the time of radiographic examinations.

\begin{tabular}{|l|l|l|l|l|l|l|}
\hline Nr. & Breed & $\begin{array}{l}\text { Age at } \\
1^{\text {st }} / 2^{\text {nd }} \text { radio- } \\
\text { graphic ex- } \\
\text { amination } \\
\text { (months) }\end{array}$ & $\begin{array}{l}\text { Height at } \\
\text { the withers } \\
\text { at } 1^{\text {st }} / 2^{\text {nd }} \\
\text { radiographic } \\
\text { examination }\end{array}$ & $\begin{array}{l}\text { Weight at } \\
1^{\text {st }} / 2^{\text {nd }} \text { radio- } \\
\text { graphic exam- } \\
\text { ination }\end{array}$ & $\begin{array}{l}\text { Age at CT } \\
\text { examination } \\
\text { (months) }\end{array}$ & $\begin{array}{l}\text { Age at path- } \\
\text { ologic ex- } \\
\text { amination } \\
\text { (months) }\end{array}$ \\
\hline 1 & $\begin{array}{l}\text { Swiss } \\
\text { Braunvieh }\end{array}$ & 4 & $76 \mathrm{~cm}$ & $63 \mathrm{~kg}$ & 5 & 5 \\
\hline 3 & $\begin{array}{l}\text { Swiss } \\
\text { Braunvieh }\end{array}$ & $3 / 8$ & $89 / 104 \mathrm{~cm}$ & $92 / 153 \mathrm{~kg}$ & 4.5 & $\begin{array}{l}\text { n.d. (calf } \\
\text { still alive) }\end{array}$ \\
\hline $\begin{array}{l}\text { Braunvieh- } \\
\text { Limousin } \\
\text { cross }\end{array}$ & 16 & n.d. & $358 \mathrm{~kg}$ & n.d. & n.d. \\
\hline
\end{tabular}


Figure legends

Fig. 1 Diagnostic imaging and pathomorphologic preparation of the left forelimb of calf 1

with severe skeletal changes a) Orthogonal radiographic views of the left forelimb at 4 months of age show concentric rings of increased radiopacity in the carpal bones and metaphyses and epiphyses of the metacarpus, cortical thickening and medullary sclerosis, and mild dorsal deviation of the digital axis (asterisk)

b) Dorsal reconstruction of computed tomographic images taken at 5 months of age (green lines indicate sections transverse to the longitudinal axis) show the concentric layers of increased attenuation ('bone-in-bone', white arrowheads), the thickening of the cortex at the level of mid-diaphysis (white arrows) and the sclerosis of the medullary cavity (black arrowheads) c) Longitudinal section of the left forelimb of calf 1 at 19 weeks of age in the transverse plane showing compacted bone structures with a white to beige circular appearance (carpal bones, 'bone-in-bone' appearance) or with an elongated dense white to beige appearance near the epiphysis and in the metaphysis of the metacarpal bone. The normal colour of the bone and medullary cavity is red.

Fig. 2 Plantarodorsal (a) and lateromedial (c) radiographic views of the metatarsal bone of the left hind limb of calf 2 at three months showing mild patchy sclerosis of the distal metaphysis, which is interrupted by transverse radiolucent zones (white arrows), and mild cortical thickening of the diaphysis (white arrowheads). Corresponding radiographic findings at the age of eight months are shown in b) and d); the changes are less pronounced than at three months. There is increased radiodensity of the medullary cavity and the diaphyseal cortex (black arrowheads). There is reorganisation of the banded structure of the metaphysis seen at three months of age and a moderate irregular sclerosis of the metaphyseal trabeculae. 